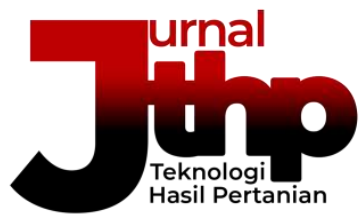

Jurnal Teknologi Hasil Pertanian. 13(2), 84-93

URL: https://jurnal.uns.ac.id/ilmupangan/article/view/42716

DOi: https://doi.org/10.20961/jthp.v13i2.42716

ISSN 1979-0309 (Online) 2614-7920 (Print)

\title{
EFEK EVAPORASI DAN SUHU PENGERINGAN SPRAYDRYING TERHADAP KARAKTERISTIK FISIK DAN KIMIA WHEY BUBUK
}

\section{THE EFFECT OF EVAPORATION AND SPRAYDRYING TEMPERATURE ON PHYSICAL AND CHEMICAL CHARACTERISTICS OF WHEY POWDER}

\author{
Syamsul Huda \\ Departemen Teknologi Industri Pangan, Fakultas Teknologi Industri Pertanian, Universitas Padjadjaran \\ Jl. Raya Bandung-Sumedang KM 21 \\ Email: syamsul.huda@unpad.ac.id
}

Diserahkan [8 Juli 2020]; Diterima [17 Agustus 2020]; Dipublikasi [20 Agusrus 2020]

\begin{abstract}
Whey is a by-product (waste) of cheese making with rennet coagulant. The percentage of whey produced was relatively high $( \pm 93.2 \%)$ than the cheese obtained. Whey contain whey protein and lactose which has high nutritional content. It is more valuable to be manufactured as whey powder. Spray drying is a drying method that is widely used in the food industry because it has a high drying speed. The evaporation process can reduce the drying load on spray drying. This study aimed to observe the physical and chemical characteristics of whey powder produced by spray drying at three different drying temperatures $160,165,170,175$, and $180^{\circ} \mathrm{C}$ and with two types of pre-drying treatments consist of evaporation and without evaporation of whey. The research method used was an experimental method with 2 replications. Observation parameters included water content, rate and level of hygroscopicity, lightness, and yield, as well as supporting parameters consist of protein and lactose content. The results obtained indicated that the evaporation and without evaporation treatments at a drying temperature of $160-180^{\circ} \mathrm{C}$ did not significantly affect water content, hygroscopic rate, hygroscopicity, and color of the whey powder. The yield in the evaporation treatment was significantly lowered compared to that of nonevaporation treatment due to the sticky phenomenon of lactose content on the drying wall chamber. The increasing temperature only significantly affected the moisture content of the whey powder sample without evaporation, while other parameters were not significantly influenced. The resulted whey powder contained $10.85 \%$ protein and $74.20 \%$ lactose. These results indicated that the evaporation process should be carried out at a temperature of $160-180^{\circ} \mathrm{C}$ because it did not alter the required parameters significantly so that the high drying load in the spray drying process can be reduced.
\end{abstract}

Keywords: whey, whey powder, spray drying, drying, hygroscopicity

\section{ABSTRAK}

Whey merupakan produk samping (limbah) dari pembuatan keju dengan koagulan rennet. Persentase whey yang dihasilkan tergolong tinggi $( \pm 93,2 \%)$ daripada keju yang diperoleh. Whey masih memiliki kandungan nutrisi yang tinggi yaitu whey protein dan laktosa sehingga perlu dimanfaatkan menjadi whey bubuk. Spray drying adalah metode pengeringan yang banyak dipakai di industri pangan karena memiliki kecepatan pengeringan yang tinggi. Proses evaporasi dapat mengurangi beban pengeringan pada spray drying. Penelitian ini bertujuan untuk mengamati karakteristik fisik dan kimia whey bubuk yang dihasilkan melalui metode spray drying pada suhu pengeringan yang berbeda yaitu suhu $160,165,170,175$, dan $180^{\circ} \mathrm{C}$ dan adanya perlakuan prapengeringan yaitu evaporasi dan non-evaporasi pada whey. Metode penelitian yang digunakan adalah metode eksperimental dengan 2 kali ulangan. Parameter pengamatan meliputi kadar air, laju dan tingkat higroskopisitas, nilai kecerahan, dan rendemen, serta pengamatan penunjang yaitu kandungan protein dan laktosa. Hasil yang diperoleh menunjukkan bahwa perlakuan evaporasi dan tanpa evaporasi pada suhu pengeringan $160-180^{\circ} \mathrm{C}$ tidak memberikan hasil yang berbeda nyata pada kadar air, laju higroskopistas, tingkat higroskopisitas, dan warna. Rendemen pada perlakuan evaporasi memberikan hasil yang berbeda nyata karena terjadi fenomena lengket pada dinding tabung pengering akibat kandungan laktosa yang tinggi. Peningkatan suhu hanya memberikan hasil yang berbeda nyata pada kadar air sampel whey bubuk tanpa evaporasi sedangkan parameter lainnya tidak berbeda 
nyata. Whey bubuk yang dihasilkan memiliki kandungan protein $10,85 \%$ dan laktosa 74,20\%. Hasil tersebut menunjukkan bahwa proses evaporasi perlu dilakukan pada suhu $160-180^{\circ} \mathrm{C}$ karena tidak banyak mengubah parameter seperti yang disebutkan sehingga beban pengeringan yang tinggi pada proses spray drying bisa berkurang.

Kata kunci: whey, whey bubuk, spray drying, pengeringan, higroskopis.

\section{PENDAHULUAN}

Whey merupakan produk samping (limbah) berbentuk cair setelah dilakukan proses pemisahan koagulan dari susu pada proses pembuatan keju. Pada pembuatan keju, bahan baku susu sebanyak $10 \mathrm{~kg}$ menghasilkan sekitar $1 \mathrm{~kg}$ keju dan $9 \mathrm{~kg}$ whey. Pembuangan whey secara langsung pada sumber air menyebabkan pencemaran air dan bau lingkungan yang tidak sedap karena whey memiliki nilai chemical oxygen demand (COD: $73-86 \mathrm{~kg} / \mathrm{m}^{3}$ ) dan biochemical oxygen demand (BOD: 38-46 $\mathrm{kg} / \mathrm{m}^{3}$ ) yang tinggi (Chandan \& Kilara, 2011). Cairan whey mengandung sekitar $6,8 \%$ total padatan yang terdiri dari laktosa dan protein whey sebagai komponen utamanya sedangkan sisanya sebanyak 93,2\% adalah air (Law \& Tamime, 2010). Protein whey memiliki nilai kecernaan asam amino tertinggi sebesar 1,0 yang merupakan indikator kemampuannya untuk memasok semua asam amino essensial ke tubuh (Domínguez-Niño et al., 2018). Sedangkan laktosa dapat membantu penyerapan mineral esensial seperti kalsium (Ca), magnesium $(\mathrm{Mg})$, dan fosfor $(\mathrm{P})$, dan penggunaan vitamin C (Ramos et al., 2015). Whey yang sudah dikeringkan dalam bentuk bubuk banyak dimanfaatkan dalam industri pangan baik untuk meningkatkan gizi maupun membantu memperbaiki kualitas produk seperti sebagai pengganti padatan susu, perbaikan warna pada produk bakeri dan konfeksioneri (Domínguez-Niño et al., 2018; Guo, 2019). Kebutuhan whey bubuk Indonesia sebagian besar diimport dari luar negeri terutama dari Eropa, Australia, dan USA. Pada tahun 2011 impor whey bubuk dari Eropa saja berada di nilai 115 juta Euro dan pada tahun 2015 meningkat menjadi 168 juta Euro. (European Commission, 2016). Kondisi ini menunjukkan bahwa diperlukan whey bubuk dari dalam negeri untuk mengurangi ketergantungan pada impor karena kebutuhan industri pangan di Indonesia terhadap whey bubuk cukup tinggi.

Whey bubuk diperoleh dari pengeringan whey segar yang telah dipasteurisasi tanpa penambahan bahan pengawet. Whey bubuk mengandung semua unsur pokok dari whey segar, kecuali air pada proporsi yang relatif sama (Chandan et al., 2015). Spray drying adalah metode pengeringan yang mengubah bahan berbentuk cair menjadi produk kering berbentuk bubuk. Spray dryer adalah alat utama pengeringan produk berbentuk cair yang sensitif terhadap panas seperti produk pangan dan biologi (Samantha et al., 2015). Kelebihan spray drying adalah sistem produksinya bersifat kontinyu dan waktu proses pengeringan yang relatif lebih cepat dibandingkan metode pengeringan lainnya (Domínguez-Niño et al., 2018). Spray drying adalah metode pengeringan dimana produk yang dihasilkan bergantung pada karakteristik bahan dan konfigurasi alat. Konfigurasi alat pengering yang meliputi suhu inlet, suhu outlet, laju alir bahan, dan laju aspirator, yang dikombinasikan pada sistem akan memengaruhi produk akhir yang dihasilkan. Suhu inlet pengeringan merupakan salah satu variabel penting pada proses spray drying. Parameter suhu inlet dapat memengaruhi efisiensi pengeringan, jumlah air yang dihilangkan, kadar air produk, dan karakteristik produk akhir yang diharapkan (Samantha et al., 2015). Beberapa penelitian sebelumnya melaporkan bahwa pada suhu $180^{\circ} \mathrm{C}$ merupakan suhu optimal spray drying untuk protein whey yang dikeringkan (Toro-Sierra et al., 2013). Menurut Tamime (2009) suhu inlet 160$180^{\circ} \mathrm{C}$ tidak memberikan kerusakan protein yang berlebih. Berdasarkan hal tersebut suhu inlet yang diaplikasikan pada penelitian ini adalah pada rentang suhu $160-180^{\circ} \mathrm{C}$ untuk mengetahui apakah terdapat perbedaan karakterisik fisik dan kimia pada whey bubuk yang dihasilkan. Salah satu kekurangan metode spray drying adalah membutuhkan konsumsi energi yang tinggi yaitu sekitar 
3500-4500 MJ/ton air yang hilang karena untuk menguapkan air dalam waktu yang singkat. Salah satu cara untuk mengurangi beban pengeringan adalah dengan menguapkan air pada bahan terlebih dahulu melalui proses evaporasi sebelum dilakukan spray drying. Proses evaporasi diketahui memiliki konsumsi energi yang lebih rendah dibandingkan spray drying sebagai contoh evaporator TVR (Thermal Vapor Recompression) membutuhkan konsumsi energi $500 \mathrm{MJ}$ per ton air yang hilang (Jong et al., 2010). Berdasarkan hal tersebut perlu dilakukan perlakuan pra-pengeringan yaitu evaporasi sebelum proses spray drying dilakukan. Perlakuan pra-pengeringan merupakan perlakuan pendahuluan yang diterapkan untuk mendapatkan karakteristik bahan yang sesuai sebelum dilakukan proses pengeringan dan bertujuan agar proses pengeringan berjalan lebih efisien. Beberapa perlakuan pra-pengeringan pada whey meliputi pemisahan keju halus, defatting (pemisahan whey cream), dan evaporasi (Guo, 2019). Dari penjelasan di atas tujuan penelitian ini adalah untuk mempelajari pengaruh evaporasi dan suhu pengeringan spray drying terhadap beberapa karakteristik whey bubuk.

\section{METODE PENELITIAN}

\section{Bahan}

Bahan baku yang digunakan pada percobaan pendahuluan adalah susu sapi segar yang berasal dari Fakultas Peternakan, Universitas Padjadjaran, Jatinangor dan untuk koagulasi susu digunakan enzim rennet komersial (produksi Danisco).

\section{Alat}

Alat-alat utama yang digunakan yaitu cream separator (Armfield FT-15), rotary vacuum evaporator (Buchi R-200), mini spray drier (Buchi B-290), Chromameter Konica Minolta (CR-400).

\section{Tahapan Penelitian}

\section{Rancangan percobaan}

Penelitian dilakukan menggunakan metode eksperimen dengan 10 perlakuan dan 2 kali ulangan. Adapun perlakuan yang diujikan dapat dilihat pada Tabel 1.

Tabel 1 Perlakuan Penelitian yang Diujikan

\begin{tabular}{lccccc}
\hline \multirow{2}{*}{ Evaporasi (A) } & \multicolumn{5}{c}{ Suhu Inlet Pengeringan (B) } \\
\cline { 2 - 6 } & $160^{\circ} \mathrm{C}$ & $165^{\circ} \mathrm{C}$ & $170^{\circ} \mathrm{C}$ & $175^{\circ} \mathrm{C}$ & $180{ }^{\circ} \mathrm{C}$ \\
\hline Non-evaporasi & $\mathrm{A}_{1} \mathrm{~B}_{1}$ & $\mathrm{~A}_{1} \mathrm{~B}_{2}$ & $\mathrm{~A}_{1} \mathrm{~B}_{3}$ & $\mathrm{~A}_{1} \mathrm{~B}_{4}$ & $\mathrm{~A}_{1} \mathrm{~B}_{5}$ \\
Evaporasi & $\mathrm{A}_{2} \mathrm{~B}_{1}$ & $\mathrm{~A}_{2} \mathrm{~B}_{2}$ & $\mathrm{~A}_{2} \mathrm{~B}_{3}$ & $\mathrm{~A}_{2} \mathrm{~B}_{4}$ & $\mathrm{~A}_{2} \mathrm{~B}_{5}$ \\
\hline
\end{tabular}

\section{Tahapan pembuatan whey bubuk}

Proses diawali dengan pemisahan whey dari susu segar (Law \& Tamime, 2010) meliputi (1). Susu dipanaskan pada suhu pasteurisasi $72^{\circ} \mathrm{C}$ dengan menggunakan waterbath dan ditahan selama 15 detik untuk membunuh bakteri patogen (2). Pendinginan susu pada suhu $32^{\circ} \mathrm{C}$ (3). Penambahan rennet dan pembentukan dadih, setelah rennet ditambahkan, wadah ditutup dan dibiarkan selama 1 jam sampai terbentuk dadih susu seperti massa jeli (4). Pemotongan dadih dan pemanasan $\left(60^{\circ} \mathrm{C}\right)$ membantu memisahkan whey dari dadih. (5). Whey dipisahan dari dadih dengan cara penyaringan. Tahap berikutnya mengikuti metode Chandan \& Kilara (2011). Cairan whey yang didapat masih mengandung sedikit lemak susu. Lemak susu dipisahkan dengan menggunakan cream separator. Cairan whey dipanaskan sampai suhu $55^{\circ} \mathrm{C}$ kemudian dimasukkan ke dalam alat pemisah lemak/cream separator, hingga diperoleh 2 fase yaitu cream whey dan whey. Whey dievaporasi dalam keadaan vakum dengan menggunakan rotary vacuum evaporator pada tekanan 175 mbar selama 30 menit dengan suhu awal whey $25^{\circ} \mathrm{C}$ yang akan memisahkan air sebanyak $30 \%$ sehingga konsentrasi whey protein dalam cairan whey akan lebih tinggi. Laju kondensor diatur dengan debit $200 \mathrm{ml} / 10$ detik. Kecepatan putaran labu didih diatur pada skala 3 dan evaporator mulai dijalankan pada suhu $30^{\circ} \mathrm{C}$. Proses evaporasi dilakukan pada suhu distilasi $47^{\circ} \mathrm{C}$ dan ditahan selama 30 menit dan mulai pada suhu ini waktu penghitungan selama 30 menit dimulai. Sampel whey yang 
telah dievaporasi selanjutnya dikeringkan dengan menggunakan spray dryer pada suhu yang telah ditentukan sesuai perlakuan yaitu pada suhu inlet $160^{\circ} \mathrm{C}, 165^{\circ} \mathrm{C}, 170^{\circ} \mathrm{C}, 175^{\circ} \mathrm{C}$, dan $180^{\circ} \mathrm{C}$ dengan suhu outlet $80^{\circ} \mathrm{C}$. Suhu pengeringan diatur dengan mengatur suhu inlet pada panel spray dryer. Suhu outlet $\left(80^{\circ} \mathrm{C}\right)$, laju aspirator $(100 \%)$, laju spray flow (skala alat di $25 \mathrm{~mm}$ ), laju pemompaan (25$33 \%$ ) dan nozzle cleaner (5) berada pada nilai konstan untuk semua perlakuan dengan terlebih dahulu melakukan trials dan errors hingga didapat nilai paling optimum tersebut.

\section{Parameter pengamatan}

Kadar Air Metode Gravimetri (Schuck et al., 2012)

Sampel sebanyak 0,5 gram dimasukkan ke dalam cawan kering kemudian dimasukkan ke dalam oven yang diatur pada suhu $102^{\circ} \mathrm{C} \pm 2{ }^{\circ} \mathrm{C}$ selama 2 jam. Sampel yang telah kering dimasukkan dalam desikator untuk didinginkan kemudian ditimbang. Pengeringan dilakukan kembali sampai diperoleh berat yang konstan. Kadar air sampel dihitung dengan rumus:

Kadar air $(\%$ b.b $)=\frac{a-b}{a} \times 100 \%$

Keterangan:

$\mathrm{a}=$ berat awal sampel $(\mathrm{g})$

$\mathrm{b}=$ berat sampel setelah dikeringkan $(\mathrm{g})$

Laju Higroskopisitas (Schuck et al., 2012)

Tabel 2 Klasifikasi Produk Bubuk Berdasarkan Higroskopisitas pada RH $75 \%$

\begin{tabular}{llc}
\hline No & \multicolumn{1}{c}{ Jenis } & $\begin{array}{c}\text { Higroskopisitas } \\
(\%) \text { pada } \mathrm{RH} \\
75 \%\end{array}$ \\
\hline 1. & $\begin{array}{l}\text { Non-hygroscopic } \\
\text { powder }\end{array}$ & $\leq 10,0$ \\
2. & $\begin{array}{l}\text { Slightly } \\
\text { hygroscopic } \\
\text { powder }\end{array}$ & $10,1-15,0$ \\
3. & $\begin{array}{l}\text { Hygroscopic } \\
\text { powder } \\
\text { Very hygroscopic } \\
\text { powder } \\
\text { Extremely } \\
\text { hygroscopic } \\
\text { powder }\end{array}$ & $20,1-25,0$ \\
\hline
\end{tabular}

Sampel sebanyak 0,5 gram ditempatkan dalam cawan pada desikator yang memiliki RH terkontrol $75 \%$. Kenaikan berat sampel dicatat setiap 60 menit sampai diperoleh berat yang konstan. Laju higroskopisitas diperoleh dari slope grafik antara waktu penimbangan dan berat sampel.

Tingkat Higroskopisitas (Schuck et al., 2012)

Sampel sebanyak 0,5 gram ditempatkan dalam cawan pada desikator yang memiliki RH terkontrol $75 \%$. Kenaikan berat sampel dicatat sampai diperoleh berat yang konstan. Tingkat higroskopisitas dihitung dengan persamaan:

\%Higroskopisitas

$$
=\frac{(\% W i+\% F W) \times 100}{100+\% W i}
$$

Keterangan:

$\% \mathrm{FW}=$ kadar air awal bahan

$\% \mathrm{Wi}=$ (Berat air yang terserap/Berat bahan) x $100 \%$.

Tingkat Kecerahan (L*) (Schuck et al., 2012)

Sampel ditempatkan dalam wadah pengukuran. Tempatkan wadah berisi sampel pada chromameter. Tekan tombol tembak pada alat chromameter. Cetak hasil pengukuran pada alat. Hasil pengukuran berupa tingkat kecerahan produk akan didapatkan.

Rendemen (Schuck et al., 2012).

Rendemen dihitung sebagai rasio antara jumlah bubuk whey yang tertampung (gram) dalam wadah penampung setelah proses spray drying terhadap jumlah sampel awal sebelum proses spray drying $(\mathrm{mL})$

Pengamatan penunjang dilakukan pada sampel whey bubuk yang mengalami proses pengolahan paling intensif yaitu sampel evaporasi dengan perlakuan suhu inlet tertinggi yaitu $180^{\circ} \mathrm{C}$. Parameter yang diamati meliputi kadar protein metode mikro KjeldahL (Schuck et al., 2012) dan kadar laktosa (Schuck et al., 2012).

Data hasil penelitian dianalisis secara statistik menggunakan software SPSS versi 22. Untuk melihat ada tidaknya perbedaan antara suhu inlet pengeringan terhadap variabel pengamatan digunakan analisis regresi linear sederhana sedangkan untuk melihat ada tidaknya perbedaan antara 
perlakuan evaporasi dan non-evaporasi digunakan uji $\mathrm{T}$ berpasangan. Jika nilai $\mathrm{P}<$ 0,05 maka terdapat perbedaan yang nyata pada perlakuan (Santoso, 2017).

\section{HASIL DAN PEMBAHASAN}

\section{Kadar Air}

Kadar air dari whey bubuk untuk perlakuan dengan dan tanpa evaporasi pada beberapa suhu pengeringan dapat dilihat pada Tabel 3.

Berdasarkan uji $\mathrm{T}$ berpasangan, perlakuan evaporasi dan non-evaporasi tidak berbeda nyata $(\mathrm{P}>0,05)$ yang artinya bahwa tidak ada pengaruh perlakuan evaporasi dan tanpa evaporasi pada whey sebelum dilakukan pengeringan terhadap kadar air whey bubuk yang dihasilkan. Uji regresi linear sederhana pada perlakuan nonevaporasi menunjukkan bahwa perlakuan suhu yang diberikan memberikan hasil yang berbeda nyata $(\mathrm{P}<0,05)$ yang artinya bahwa ada pengaruh suhu pengeringan terhadap kadar air whey bubuk yang dihasilkan. Semakin tinggi suhu pengeringan semakin tinggi pula kadar air whey bubuk yang dihasilkan. Sedangkan pada perlakuan evaporasi, uji regresi linear sederhana menunjukkan bahwa perlakuan pada suhu yang diberikan memberikan hasil yang tidak berbeda nyata $(\mathrm{P}>0,05)$ yang artinya bahwa tidak ada pengaruh suhu pengeringan terhadap kadar air whey bubuk yang dihasilkan.
Kadar air whey bubuk menurut Food and Agriculture Organization of the United Nations (2010) maksimal 5\% dimana semua sampel whey bubuk yang dihasilkan pada penelitian ini memiliki kadar air di bawah 5\%. Pada data hasil penelitian, kadar air sampel perlakuan tanpa evaporasi meningkat seiring dengan meningkatnya suhu pengeringan. Hasil tersebut berbeda dengan beberapa hasil penelitian sebelumnya, dimana kenaikan suhu pengeringan akan menurunkan kadar air pada beberapa produk pangan seperti bubuk hidrolisat protein dan bubuk sari buah (Samantha et al., 2015). Perbedaan tersebut diduga karena pada suhu yang lebih tinggi akan menghasilkan produk dengan kadar air yang lebih rendah dan lebih mudah menyerap air sehingga lebih higroskopis. Hal tersebut berhubungan dengan lebih tingginya perbedaan konsentrasi air yang terkandung pada produk dengan lingkungan (Samantha et al., 2015). Bahan higroskopis menyebabkan produk lebih mudah mengikat air dari lingkungan sehingga produk menjadi lengket dan dapat menyebabkan perubahan kadar air selama penyimpanan. Hal tersebut dapat menjadi indikasi bahwa kadar air produk setelah proses pengeringan sangat rendah dan memiliki tingkat higroskopisitas yang cukup tinggi sehingga memerlukan penanganan yang lebih cepat saat pengambilan produk dari spray dryer dan dikemas menggunakan kemasan yang kedap uap air untuk menghindari peningkatan kadar air pada produk.

Tabel 3 Kadar air whey bubuk untuk perlakuan dengan dan tanpa evaporasi pada suhu pengeringan yang berbeda.

\begin{tabular}{|c|c|c|c|c|c|}
\hline \multirow[b]{2}{*}{$\begin{array}{l}\text { Suhu } \\
\left({ }^{\circ} \mathrm{C}\right)\end{array}$} & \multicolumn{4}{|c|}{ Perlakuan } & \multirow[b]{2}{*}{$\begin{array}{c}\text { Uji T (Non- } \\
\text { Evaporasi vs } \\
\text { Evaporasi) }\end{array}$} \\
\hline & $\begin{array}{c}\text { Non- } \\
\text { Evaporasi }\end{array}$ & $\begin{array}{c}\text { Uji Regresi } \\
\text { Linear } \\
\text { Sederhana (Suhu } \\
\text { vs Kadar air) }\end{array}$ & Evaporasi & $\begin{array}{c}\text { Uji Regresi } \\
\text { Linear Sederhana } \\
\text { (Suhu vs Kadar } \\
\text { air) }\end{array}$ & \\
\hline 160 & $3,18 \pm 0,71 \%$ & \multirow{5}{*}{$\begin{array}{l}Y=0,067 \mathrm{X}- \\
7,712 \\
\mathrm{R} \text { Square }= \\
0,808 \\
\text { P Value }=0,038 \\
\text { Signifikansi : } \\
\text { Signifikan }\end{array}$} & $3,67 \pm 0,11 \%$ & \multirow{5}{*}{$\begin{array}{l}Y=0,005 X+ \\
2,5 \\
R \text { Square }=0,009 \\
P \text { Value }=0,880 \\
\text { Signifikansi : } \\
\text { Tidak Signifikan }\end{array}$} & \multirow{5}{*}{$\begin{array}{l}\text { P Value = } \\
0,361 \\
\text { Signifikansi } \\
\text { Tidak } \\
\text { Signifikan }\end{array}$} \\
\hline 165 & $3,10 \pm 0,83 \%$ & & $2,73 \pm 0,16 \%$ & & \\
\hline 170 & $3,55 \pm 0,01 \%$ & & $3,64 \pm 0,06 \%$ & & \\
\hline 175 & $3,65 \pm 0,57 \%$ & & $3,10 \pm 0,11 \%$ & & \\
\hline 180 & $4,57 \pm 0,48 \%$ & & $3,61 \pm 0,00 \%$ & & \\
\hline
\end{tabular}


Tabel 4 Laju higroskopisitas (gram $\mathrm{H}_{2} \mathrm{O}$ /menit) whey bubuk untuk perlakuan dengan dan tanpa evaporasi pada suhu pengeringan yang berbeda.

\begin{tabular}{|c|c|c|c|c|c|}
\hline \multirow{6}{*}{$\begin{array}{l}\text { Suhu } \\
\left({ }^{\circ} \mathrm{C}\right)\end{array}$} & \multicolumn{4}{|c|}{ Perlakuan } & \multirow{6}{*}{$\begin{array}{c}\text { Uji T (Non- } \\
\text { Evaporasi } \\
\text { vs } \\
\text { Evaporasi) }\end{array}$} \\
\hline & \multirow{5}{*}{ Non-Evaporasi } & \multirow{5}{*}{$\begin{array}{c}\text { Uji Regresi } \\
\text { Linear } \\
\text { Sederhana } \\
\text { (Suhu vs } \\
\text { Kadar air) }\end{array}$} & \multirow{5}{*}{ Evaporasi } & \multirow{5}{*}{$\begin{array}{c}\text { Uji Regresi } \\
\text { Linear } \\
\text { Sederhana } \\
\text { (Suhu vs } \\
\text { Kadar air) }\end{array}$} & \\
\hline & & & & & \\
\hline & & & & & \\
\hline & & & & & \\
\hline & & & & & \\
\hline & $2,08 \pm 0,000030$ & $Y=1,32 \times 10^{-6}$ & $2,22 \pm 0,000012$ & $Y=-8,00 \times 10^{-7}$ & \multirow{6}{*}{$\begin{array}{l}\text { P Value = } \\
0,375 \\
\text { Signifikansi } \\
\text { Tidak } \\
\text { Signifikan }\end{array}$} \\
\hline 160 & $\mathrm{x} 10^{-4}$ & $X-3,24 \times 10^{-5}$ & $\mathrm{x} 10^{-4}$ & $X+0,0003$ & \\
\hline 165 & $\begin{array}{c}1,24 \pm 0,000142 \\
\times 10^{-4}\end{array}$ & $\begin{array}{l}\text { R Square }= \\
0,071\end{array}$ & $\begin{array}{c}2,07 \pm 0,000006 \\
\times 10^{-4}\end{array}$ & $\begin{array}{l}\text { R Square }= \\
0,538\end{array}$ & \\
\hline 170 & $\begin{array}{c}2,16 \pm 0,000018 \\
\times 10^{-4}\end{array}$ & $\begin{array}{l}\text { P Value }= \\
0,665\end{array}$ & $\begin{array}{c}2,13 \pm 0,000008 \\
\times 10^{-4}\end{array}$ & $\begin{array}{l}\text { P Value }= \\
0.158\end{array}$ & \\
\hline 175 & $\begin{array}{c}2,18 \pm 0,000008 \\
\times 10^{-4}\end{array}$ & $\begin{array}{l}\text { Signifikansi: } \\
\text { Tidak }\end{array}$ & $\begin{array}{c}1,99 \pm 0,000018 \\
\times 10^{-4}\end{array}$ & $\begin{array}{l}\text { Signifikansi: } \\
\text { Tidak }\end{array}$ & \\
\hline 180 & $\begin{array}{c}1,94 \pm 0,000011 \\
\times 10^{-4}\end{array}$ & Signifikan & $\begin{array}{c}2,06 \pm 0,000015 \\
\times 10^{-4}\end{array}$ & Signifikan & \\
\hline
\end{tabular}

Keterangan:

Jika P Value $<0,05$ maka terdapat perbedaan nyata pada perlakuan

\section{Laju dan Tingkat Higroskopisitas}

Laju higroskopisitas adalah kecepatan bahan menyerap air per waktu. Sedangkan tingkat higroskopisitas adalah kandungan akhir bahan setelah ditempatkan dalam udara dengan RH terkondisikan. Produk nonhigroskopis memiliki tingkat higroskopisitas di bawah 10\% (Schuck et al., 2012). Laju higroskopisitas dari whey bubuk untuk perlakuan dengan dan tanpa evaporasi pada beberapa suhu pengeringan dapat dilihat pada Tabel 4. Laju higroskopisitas whey bubuk berada dalam kisaran $1,24 \times 10^{-4}$ sampai $2,22 \times 10^{-4}$ gram $\mathrm{H}_{2} \mathrm{O} /$ menit.

Pada Tabel 4, berdasarkan uji $\mathrm{T}$ berpasangan, perlakuan evaporasi dan nonevaporasi tidak berbeda nyata $(\mathrm{P}>0,05)$ yang artinya bahwa tidak ada pengaruh perlakuan evaporasi dan tanpa evaporasi whey sebelum dilakukan pengeringan terhadap laju higroskopitas whey bubuk yang dihasilkan. Uji regresi linear sederhana pada perlakuan non-evaporasi menunjukkan bahwa perlakuan suhu memberikan hasil yang tidak berbeda nyata $(\mathrm{P}>0,05)$ yang artinya bahwa tidak ada pengaruh suhu pengeringan terhadap laju higroskopisitas whey bubuk yang dihasilkan. Hasil yang sama, pada perlakuan evaporasi, uji regresi linear sederhana menunjukkan bahwa perlakuan suhu memberikan hasil yang tidak berbeda nyata $(\mathrm{P}>0,05)$ yang artinya bahwa ada tidak pengaruh suhu pengeringan terhadap laju higroskopositas whey bubuk yang dihasilkan.

Berdasarkan uji $\mathrm{T}$ berpasangan, perlakuan evaporasi dan non-evaporasi tidak berbeda nyata $(\mathrm{P}>0,05)$ yang artinya bahwa tidak ada pengaruh perlakuan evaporasi dan tanpa evaporasi whey cair sebelum pengeringan terhadap tingkat higroskopitas whey bubuk yang dihasilkan. Uji regresi linear sederhana pada perlakuan nonevaporasi menunjukkan bahwa perlakuan suhu memberikan hasil yang tidak berbeda nyata $(\mathrm{P}>0,05)$ yang artinya bahwa tidak ada pengaruh suhu pengeringan terhadap tingkat higroskopisitas whey bubuk yang dihasilkan. Hasil yang sama, pada perlakuan evaporasi, uji regresi linear sederhana menunjukkan bahwa perlakuan suhu memberikan hasil yang tidak berbeda nyata $(\mathrm{P}>0,05)$ yang artinya bahwa ada tidak ada pengaruh suhu pengeringan terhadap tingkat higroskopositas whey bubuk yang dihasilkan. 
Tabel 5 Tingkat higroskopisitas whey bubuk untuk perlakuan dengan dan tanpa evaporasi pada suhu pengeringan yang berbeda.

\begin{tabular}{|c|c|c|c|c|c|}
\hline \multirow[b]{2}{*}{$\begin{array}{l}\text { Suhu } \\
\left({ }^{\circ} \mathrm{C}\right)\end{array}$} & \multicolumn{4}{|l|}{ Perlakuan } & \multirow[b]{2}{*}{$\begin{array}{c}\text { Uji T (Non- } \\
\text { Evaporasi } \\
\text { vs } \\
\text { Evaporasi) }\end{array}$} \\
\hline & $\begin{array}{c}\text { Non- } \\
\text { Evaporasi }\end{array}$ & $\begin{array}{c}\text { Uji Regresi } \\
\text { Linear } \\
\text { Sederhana (Suhu } \\
\text { vs Kadar air) }\end{array}$ & Evaporasi & $\begin{array}{c}\text { Uji Regresi } \\
\text { Linear } \\
\text { Sederhana (Suhu } \\
\text { vs Kadar air) } \\
\end{array}$ & \\
\hline 160 & $15,80 \pm 0,69$ & \multirow{5}{*}{$\begin{array}{l}Y=0,015 \mathrm{X}- \\
13,388 \\
\mathrm{R} \text { Square }= \\
0,155 \\
\text { P Value }=0,512 \\
\text { Signifikansi: } \\
\text { Tidak Signifikan }\end{array}$} & $16,85 \pm 0,10$ & \multirow{5}{*}{$\begin{array}{l}\text { Y }=-0,006 \mathrm{X}+ \\
17,212 \\
\mathrm{R} \text { Square }= \\
0,007 \\
\text { P Value }=0,892 \\
\text { Signifikansi: } \\
\text { Tidak Signifikan }\end{array}$} & \multirow{5}{*}{$\begin{array}{l}\text { P Value = } \\
0,323 \\
\text { Signifikansi: } \\
\text { Tidak } \\
\text { Signifikan }\end{array}$} \\
\hline 165 & $15,74 \pm 0,49$ & & $15,40 \pm 0,28$ & & \\
\hline 170 & $16,29 \pm 0,64$ & & $16,36 \pm 0,31$ & & \\
\hline 175 & $15,63 \pm 0,26$ & & $15,90 \pm 0,42$ & & \\
\hline 180 & $16,23 \pm 0,11$ & & $16,45 \pm 0,01$ & & \\
\hline
\end{tabular}

Keterangan:

Jika P Value $<0,05$ maka terdapat perbedaan nyata pada perlakuan

Pada Tabel 5 dapat dilihat bahwa tingkat higroskopisitas perlakuan berkisar antara $15 \%$ sampai dengan $17 \%$ yang artinya bahan tersebut tergolong ke dalam bahan yang higroskopis. Menurut Guo (2019) whey powder mengandung $63-75 \%$ laktosa. Seperti pada susu bubuk, jika laktosa tidak diberikan perlakuan yang tepat sebelum dikeringkan, laktosa amorf yang sangat higroskopis akan hadir pada produk akhir yang dapat menyebabkan masalah pada umur simpan yang berat seperti penggumpalan dan lengket. Untuk mengatasi hal tersebut dapat dilakukan kristalisasi laktosa terlebih dahulu sebelum spray drying agar jenis kristal $\alpha$ laktosa yang non-higroskopis yang mendominasi pada produk akhir setelah pengeringan.

\section{Nilai Kecerahan}

Nilai kecerahan dari perlakuan pengeringan dengan metode spray drying dapat dilihat pada Tabel 6. Pada Tabel 6, berdasarkan uji $\mathrm{T}$ berpasangan, perlakuan evaporasi dan non-evaporasi tidak berbeda nyata $(\mathrm{P}>0,05)$ yang artinya bahwa tidak ada pengaruh perlakuan evaporasi dan tanpa evaporasi whey sebelum dilakukan pengeringan terhadap nilai kecerahan whey bubuk yang dihasilkan. Uji regresi linear sederhana pada perlakuan non-evaporasi menunjukkan bahwa perlakuan suhu yang diberikan memberikan hasil yang tidak berbeda nyata $(\mathrm{P}>0,05)$ yang artinya bahwa tidak ada pengaruh suhu pengeringan terhadap nilai kecerahan whey bubuk yang dihasilkan. Hasil yang sama, pada perlakuan evaporasi, uji regresi linear sederhana menunjukkan bahwa perlakuan suhu yang diberikan memberikan hasil yang tidak berbeda nyata $(\mathrm{P}>0,05)$ yang artinya bahwa ada tidak pengaruh suhu pengeringan terhadap nilai kecerahan whey bubuk yang dihasilkan.

Perlakuan panas yang tinggi yang diaplikasikan pada proses spray drying dapat menyebabkan interaksi antara komponen dalam bahan yang menghasilkan warna coklat. Pencoklatan tersebut dihasilkan dari reaksi Maillard. Kandungan laktosa pada whey bubuk yang tinggi merupakan penyebab utama terjadinya reaksi Maillard. Reaksi Maillard merupakan hasil reaksi antara gula pereduksi (laktosa atau galaktosa) dengan grup asam amino bebas dari protein. Produk akhir yang dihasilkan dari reaksi Maillard yaitu melanoidin berwarna coklat yang menyebabkan penyimpangan warna yang secara estetis tidak diinginkan sehingga nilai kecerahan produk menurun (Chandan \& Kilara, 2011). 
Tabel 6 Rendemen whey bubuk untuk perlakuan dengan dan tanpa evaporasi pada suhu pengeringan yang berbeda.

\begin{tabular}{|c|c|c|c|c|c|}
\hline \multirow[b]{2}{*}{$\begin{array}{l}\text { Suhu } \\
\left({ }^{\circ} \mathrm{C}\right)\end{array}$} & \multicolumn{4}{|c|}{ Perlakuan } & \multirow[b]{2}{*}{$\begin{array}{l}\text { Uji T (Non- } \\
\text { Evaporasi } \\
\text { vs } \\
\text { Evaporasi) }\end{array}$} \\
\hline & $\begin{array}{c}\text { Non- } \\
\text { Evaporasi }\end{array}$ & $\begin{array}{c}\text { Uji Regresi } \\
\text { Linear } \\
\text { Sederhana (Suhu } \\
\text { vs Kadar air) }\end{array}$ & Evaporasi & $\begin{array}{c}\text { Uji Regresi } \\
\text { Linear } \\
\text { Sederhana (Suhu } \\
\text { vs Kadar air) }\end{array}$ & \\
\hline 160 & $101,13 \pm 0,04$ & \multirow{5}{*}{$\begin{array}{l}Y=-0,027 \mathrm{X}+ \\
105,2 \\
\mathrm{R} \text { Square }= \\
0,297 \\
\text { P Value }=0,342 \\
\text { Signifikansi: } \\
\text { Tidak Signifikan }\end{array}$} & $101,20 \pm 1,03$ & \multirow{5}{*}{$\begin{array}{l}Y=-0,033 X+ \\
106,4 \\
R \text { Square }= \\
0,642 \\
\text { P Value = } 0,103 \\
\text { Signifikansi: } \\
\text { Tidak Signifikan }\end{array}$} & \multirow{5}{*}{$\begin{array}{l}\text { P Value = } \\
0,360 \\
\text { Signifikansi: } \\
\text { Tidak } \\
\text { Signifikan }\end{array}$} \\
\hline 165 & $100,54 \pm 1,70$ & & $100,82 \pm 0,81$ & & \\
\hline 170 & $100,47 \pm 1,07$ & & $100,67 \pm 0,49$ & & \\
\hline 175 & $100,04 \pm 1,68$ & & $100,93 \pm 0,49$ & & \\
\hline 180 & $100,70 \pm 0,56$ & & $100,32 \pm 0,23$ & & \\
\hline
\end{tabular}

Keterangan:

Jika P Value $<0,05$ maka terdapat perbedaan nyata pada perlakuan

\section{Rendemen}

Rendemen whey bubuk dari perlakuan pengeringan dengan metode spray drying untuk perlakuan dengan dan tanpa proses evaporasi untuk semua level pemanasan dapat dilihat pada Tabel 7.

Pada Tabel 7, berdasarkan uji $\mathrm{T}$ berpasangan, perlakuan evaporasi dan nonevaporasi berbeda nyata $(\mathrm{P}<0,05)$ yang artinya bahwa ada pengaruh perlakuan evaporasi dan tanpa evaporasi pada whey sebelum dilakukan pengeringan terhadap rendemen whey bubuk yang dihasilkan. Uji regresi linear sederhana pada perlakuan nonevaporasi menunjukkan bahwa perlakuan suhu memberikan hasil yang tidak berbeda nyata $(\mathrm{P}>0,05)$ yang artinya bahwa tidak ada pengaruh suhu pengeringan terhadap rendemen whey bubuk yang dihasilkan. Hasil yang sama, pada perlakuan evaporasi, uji regresi linear sederhana menunjukkan bahwa perlakuan suhu memberikan hasil yang tidak berbeda nyata $(\mathrm{P}>0,05)$ yang artinya bahwa ada tidak pengaruh suhu pengeringan terhadap rendemen whey bubuk yang dihasilkan.

Rendemen whey bubuk pada perlakuan evaporasi memiliki hasil yang nyata lebih rendah dibandingkan perlakuan tanpa evaporasi padahal konsentrasi padatan pada sampel evaporasi lebih tinggi karena air telah dihilangkan sebanyak 30\%. Menurut Samantha et al., (2015) semakin tinggi konsentrasi padatan pada proses spray drying semakin dapat memicu terjadinya akumulasi bahan pada dinding tabung pengering.
Rendemen yang lebih rendah juga dikarenakan terdapat whey kering yang menempel pada dinding tabung pengering dan tidak jatuh pada wadah pengumpulan produk akhir pada alat. Whey bubuk yang diambil dari spray dryer hanya yang berasal dari wadah pengumpulan pada alat sedangkan yang menempel pada dinding pengering tidak diambil. Hal tersebut yang menyebabkan rendemen whey bubuk pada perlakuan evaporasi memiliki hasil yang lebih rendah. Fenomema menempelnya bahan kering pada dinding spray dryer disebut dengan lengket dinding (wall sticking). Menurut Lin et al., (2018) salah satu tantangan besar dalam proses spray drying adalah terjadinya fenomena lengket dinding yang dapat menurunkan produktivitas dan kualitas produk secara signifikan. Faktor utama yang memengaruhi kelengketan bahan yang memiliki gula tinggi adalah higroskopisitas, solubilitas, titik lebur, dan suhu transisi gelas. Domínguez-Niño et al., (2018) menyatakan bahwa masalah lengket dinding disebabkan adanya gula dengan berat molekul rendah dengan suhu transisi gelas yang juga rendah. Untuk alasan tersebut dapat digunakan maltodekstrin untuk mengatasinya. Maltodekstrin banyak digunakan pada proses spray drying karena memiliki suhu transisi gelas yang lebih tinggi dari laktosa, higroskopisitas rendah, mencegah terjadinya aglomerasi partikel, kelarutan yang tinggi dalam air dingin, dan ekonomis (Samantha et al., 2015; Schuck et al., 2012). 
Tabel 7 Rendemen whey bubuk untuk perlakuan dengan dan tanpa evaporasi pada suhu pengeringan yang berbeda.

\begin{tabular}{|c|c|c|c|c|c|}
\hline \multirow[b]{2}{*}{$\begin{array}{l}\text { Suhu } \\
\left({ }^{\circ} \mathrm{C}\right)\end{array}$} & \multicolumn{4}{|c|}{ Perlakuan } & \multirow[b]{2}{*}{$\begin{array}{c}\text { Uji T (Non- } \\
\text { Evaporasi } \\
\text { vs } \\
\text { Evaporasi) }\end{array}$} \\
\hline & $\begin{array}{c}\text { Non- } \\
\text { Evaporasi }\end{array}$ & $\begin{array}{c}\text { Uji Regresi } \\
\text { Linear } \\
\text { Sederhana (Suhu } \\
\text { vs Kadar air) }\end{array}$ & Evaporasi & $\begin{array}{c}\text { Uji Regresi } \\
\text { Linear } \\
\text { Sederhana (Suhu } \\
\text { vs Kadar air) }\end{array}$ & \\
\hline 160 & $4,08 \pm 0,41$ & $Y=-0,009 X+$ & $3,79 \pm 0,42$ & $Y=-0,051 X+$ & P Value = \\
\hline 165 & $3,94 \pm 0,54$ & $\begin{array}{l}5,484 \\
\text { R Square = }\end{array}$ & $3,49 \pm 0,95$ & $\begin{array}{l}11.984 \\
\text { R Square = }\end{array}$ & $\begin{array}{l}0,026 \\
\text { Signifikansi: }\end{array}$ \\
\hline 170 & $4,19 \pm 0,41$ & 0,214 & $3,73 \pm 0,16$ & 0,740 & Signifikan \\
\hline $\begin{array}{l}175 \\
180\end{array}$ & $\begin{array}{l}3,80 \pm 0,98 \\
3,93 \pm 0,01\end{array}$ & $\begin{array}{l}\text { P Value }=0,432 \\
\text { Signifikansi: } \\
\text { Tidak Signifikan }\end{array}$ & $\begin{array}{l}3,26 \pm 0,70 \\
2,64 \pm 0,99\end{array}$ & $\begin{array}{l}\mathrm{P} \text { Value }=0,061 \\
\text { Signifikansi: } \\
\text { Signifikan }\end{array}$ & \\
\hline
\end{tabular}

Keterangan:

Jika P Value $<0,05$ maka terdapat perbedaan nyata pada perlakuan

\section{Kadar Protein dan Laktosa}

Pengamatan penunjang pada penelitian ini dilakukan pada sampel whey bubuk dengan perlakuan pengolahan paling intensif yang diberikan yaitu perlakuan dengan evaporasi pada suhu pengeringan $180^{\circ} \mathrm{C}$. Sampel ini mewakili sampel penelitian karena semakin intensif proses pengolahan semakin besar pengaruhnya terhadap karakteristik produk. Sampel whey bubuk yang dihasilkan memiliki kadar protein $10,85 \%$ dan kadar laktosa 74,20\%. Kadar protein minimal whey bubuk adalah $10,0 \%$ dan kadar laktosa berada dalam kisaran 63$75 \%$ (Food and Agriculture Organization of the United Nations, 2010; Guo, 2019). Data tersebut menunjukkan bahwa whey bubuk yang dihasilkan memiliki komponen utama laktosa dimana menjadi penyebab utama terjadinya kelengketan baik pada proses spray drying maupun produk akhir yang tergolong dalam jenis produk higroskopis seperti yang telah dijelaskan sebelumnya.

\section{KESIMPULAN}

Perlakuan evaporasi dan tanpa evaporasi pada suhu pengeringan $160-180^{\circ} \mathrm{C}$ tidak memberikan hasil yang berbeda nyata pada kadar air, laju higroskopistas, tingkat higroskopisitas, dan warna. Rendemen pada perlakuan evaporasi memberikan hasil yang berbeda nyata karena terjadi fenomena lengket pada dinding tabung pengering akibat kandungan laktosa yang tinggi.
Peningkatan suhu hanya memberikan hasil yang berbeda nyata pada kadar air sampel whey bubuk tanpa evaporasi sedangkan parameter lainnya tidak berbeda nyata. Hasil tersebut menunjukkan bahwa proses evaporasi perlu dilakukan pada suhu 160$180^{\circ} \mathrm{C}$ karena tidak banyak mengubah parameter seperti yang disebutkan sehingga beban pengeringan yang tinggi pada proses spray drying bisa berkurang. Whey bubuk mengandung laktosa dalam jumlah tinggi. Proses produksi whey bubuk disarankan menggunakan bahan tambahan pangan yang dapat mengurangi kelengketan produk dan memiliki suhu transisi gelas yang tinggi agar bisa mengurangi higroskopisitas produk akhir yang dihasilkan seperti maltodekstrin ataupun gum.

\section{DAFTAR PUSTAKA}

Chandan, R. C., \& Kilara, A. (2011). Dairy Ingridients for Food Processing. Wiley Blackwell.

Chandan, R. C., Kilara, A., \& Shah, N. P. (2015). Dairy Processing and Quality Assurance: An Overview. Dairy Processing and Quality Assurance, 140.

https://doi.org/10.1002/9780813804033. ch1

Domínguez-Niño, A., Cantú-Lozano, D., Ragazzo-Sanchez, J. A., AndradeGonzález, I., \& Luna-Solano, G. (2018). Energy requirements and production 
cost of the spray drying process of cheese whey. Drying Technology, 36(5), 597-608. https://doi.org/10.1080/07373937.2017. 1350863

European Commission. (2016). The Food and Beverage Market Entry Handbook: Indonesia.a Practical Guide to the Market in Indonesia for European Agrifood Products. October, 1-232. https://doi.org/10.2818/168202

Food and Agriculture Organization of the United Nations. (2010). Codex standard for whey powders. Codex Stan, c, 289.

Guo, M. (2019). Whey Protein Production, Chemistry, Functionality, and Applications. Wiley.

Jong, P. de, Fox, M., Akkerman, C., \& Straatsma, H. (2010). Energy reduction by high dry matter concentration and drying. newfood

Law, B. A., \& Tamime, A. Y. (2010). Technology of Cheesemaking, Second Edition (Society of Dairy Technology series).

Lin, Y., Liu, Y., Wang, L., Xie, Y., Gao, Z., \& Wang, S. (2018). Optimization of drying conditions and components to reduce wall sticking during spray drying of infant formula milk. International Journal of Agricultural and Biological Engineering, 11(2), 214-218. https://doi.org/10.25165/j.ijabe.2018110 2.2788

Ramos, O. L., Pereira, R. N., Rodrigues, R.
M., Teixeira, J. A., Vicente, A. A., \& Malcata, F. X. (2015). Whey and Whey Powders: Production and Uses. In Encyclopedia of Food and Health (1st ed., Issue August). Elsevier Ltd. https://doi.org/10.1016/B978-0-12384947-2.00747-9

Samantha, S. C., Bruna, A. S. M., Adriana, R. M., Fabio, B., Sandro, A. R., \& Aline, R. C. A. (2015). Drying by spray drying in the food industry: Microencapsulation, process parameters and main carriers used. African Journal of Food Science, 9(9), 462-470. https://doi.org/10.5897/ajfs2015.1279

Santoso, S. (2017). Menguasasi Statistik dengan SPSS 24. PT. Elex Media Komputindo.

Schuck, P., Dolivet, A., \& Jeantet, R. (2012). Analytical Methods for Food and Dairy Powders. In Analytical Methods for Food and Dairy Powders. https://doi.org/10.1002/9781118307397

Tamime, A. Y. (2009). Dairy Powders and Concentrated Products. In Dairy Powders and Concentrated Products. https://doi.org/10.1002/9781444322729

Toro-Sierra, J., Schumann, J., \& Kulozik, U. (2013). Impact of spray-drying conditions on the particle size of microparticulated whey protein fractions. Dairy Science and Technology, 93(4-5), 487-503. https://doi.org/10.1007/s13594-013$0124-7$ 